make its contribution to the planning and building of a Britain that will at least be a more comfortable place in which to live.

\section{Economics and Finance}

IN an address on "Finance and the War" given to members of the Parliamentary Labour Party at the House of Commons on November 9, which has now been published by the Economic Reform Club and Institute, Prof. F. Soddy stresses the importance of distinguishing between genuine and fictitious credit if we wish to put an end to recurring economic booms and slumps and periodic world wars primarily of economic or monetary origin. We live in a world of potential abundance beyond our unscientific ancestors' powers of foreseeing, but that abundance cannot be realized until we clearly distinguish between the creation and the acquisition of wealth. All genuine money reformers are unanimous in demanding that money should not be put into circulation as a debt arbitrarily terminable, and most, if not all, that it should be paid into circulation by the nation for full value received by the nation.

In Prof. Soddy's view, the issue of new money under existing economic conditions is merely one form of forced levy in kind; for new money is a new. legal claim by the issuer to anything of equivalent value on the market, with nothing to show that it is new or that the possessor in acquiring it has not given up the equivalent value and so has the legal right to claim it back on demand. He urges that the public should be instructed by its representatives that whether Parliament levies upon it, for the purposes of national expenditure, by recovering from it some of the existing meney, by taxation, or by issuing new money, the proportion between the two forms of levy in money and in kind is dictated solely by statistical considerations to maintain a constant price-level and the money in proportion to what there is to buy, so as to secure uniform and general prosperity.

\section{Electrical Music}

A PAPER on "Electrical Music" which was read on February 1 to the Midland Section of the Institution of Junior Engineers by Dr. W. Wilson and is published in the March issue of the Journal of the Institution, summarizes in a very thorough manner the chief existing methods whereby musical sounds can be produced electrically. The most important developments have taken place in connexion with apparatus which actually create musical sounds in the first instance. The first actual mention of music as produced by an electric source was in connexion with Duddell's 'singing' arc, at the end of last century. The resistance of an electric arc decreases as the current rises. The result is that instability is produced, in the absence of a ballast resistance; thus the arc is continually going out and rekindling. If an inductance instead of a resistance is used and the whole is shunted by a capacity, a tuned circuit is formed in which the current will oscillate at a definite frequency. In so doing the current between the electrodes will actually be reversed twice per cycle, the arc going out at each reversal. No serious musical instrument has developed from the singing arc, although it achieved fame as a wireless transmitter when slightly modified by Poulsen. Within the past decade the howling of a valve in a wireless set has been a common example of electrically produced sound and it forms the basis of two musical instruments. Theremin has reproduced the conditions of the oscillating wireless set in his 'etherphone'.

The second application of the oscillating valve is for the construction of a complete electronic organ, a good example of which is that designed by Coupleux and Givelet, and installed in a number of French churches. In this there are 120 valves, which are caused to oscillate singly, and to generate a full range of notes which are very rich in harmonics. A very successful electric organ was invented by Hammond in 1934. In this there are 91 small alternators all driven from a common shaft which is itself driven by a synchronous driving motor. The sound which accompanies a talking picture can be derived from a wave track printed upon the celluloid film, through which a beam of light is projected into a photoelectric cell. Organs have been designed on this principle. In conclusion, Dr. Wilson points out the many advantages of the electrical method of producing music, especially when the electronic organ is employed. The power consumption is very low, it being usually possible to obtain all the energy required by plugging all the supply leads into any ordinary lampholder. The first cost is low, being between 30 and 40 per cent of the ordinary pipe organ, the maintenance costs are low, and it can always be trusted to maintain its exact tuning. Its progress up to the present has been remarkable, and there is every reason to foretell an equally rapid expansion of its use in the near future.

\section{Trends in Air Conditioning}

IN an article in the Electrician of January 31, some significant trends in air-conditioning plants are discussed. The proved reliability of compact highspeed condensing units has made practical completely self-contained factory-assembled and tested 'packaged' air-conditioning units of ever-increasing size. Last year they reached 25 tons, and there is every indication that they will be increasingly popular. This trend began seven or eight years ago with small, compact, self-contained room coolers of about half a ton capacity, which were offered almost as soon as compact condensing units were developed. Later came the so-called store-type coolers, package units containing a condensing unit, evaporator, fan, and controls, completely piped, wired, charged and tested at the factory. The success of these units and the development of suitable compact, high-speed, condensing units has led to the more recent factoryassembled-and-tested central plant units of $7 \frac{1}{2}-26$ tons capacity. Those incorporate the features of a carefully engineered and installed central plant air. conditioning system, but are self-contained in a sturdy 
steel frame. All piping work, oven vacuum dehydrat. ing, charging and testing of the system are under strict factory conditions. The units are usually placed in a stock room at the rear of a shop, in the basement, or on a balcony, and are connected to the occupied space by means of a suitable duct system.

\section{Radio Traffic Control in America}

A NOVEx plan to bring traffic signals into cars in the form of distinctive tones corresponding to the 'stop' and 'go' lights, may in time make a carradio a legal requirement on every car in the United States. In its present form, this traffic-control system uses the existing car radio tuned to $550 \mathrm{kc}$., thus making the system immediately available for the six million cars now equipped with auto-radios, though eventually a special small set would be employed with fixed tuning to the highway safetysignal frequency. By the use of this signal, the driver, instead of letting his attention wander from the roadway in his search for traffic signals in unfamiliar territory, would hear a pleasant low tone as long as the lights were green. When red comes $o n$, in all cars in that section of the roadway an interrupted high note would be heard similar to that caused by a crossing signal.

Recorded messages can be used for continuous repetition of a message. The small highway transmitting unit, which may be mounted on a telephone pole or a traffic light stanchion, makes use of a magnetic tape sound-recording device. A distinctive sign placed on the street in advance of a given radio zone attracts the attention of motorists to the radio system which they are approaching and gives them the frequency to which to tune their set. By means of this device, traffic can be diverted to a secondary thoroughfare from crowded highways, preventing jams before cars have a chance to pile up, and drivers can be warned of speed limits or of emergency in case of fire or accident.

\section{Data of Seismology}

From the Government of India Meteorological Department comes the valuable Seismological Bulletin for October-December 1939. Interpretations of readings of the seismograms from Agra, Bombay, Calcutta, Colombo, Dehra Dun, Hyderabad, and Kodaikanal are given. Furthermore, J. H. Sil at Poona has collected 58 non-instrumental reports of shocks, five being in October, eight in December, and the remainder in November. Three of the reports noted earthquakes reaching intensity 9 on the Rossi-Forel scale. By far the strongest shock was on November 21, 1939, at about 11 h. 1 m. G.M.T. At Gilgit stones fell from the mountains, and dust spread all over the valley. At Drosh intensity 9 was reached, whilst at Srinagar the walls of the observatory and other buildings cracked.

The Seismological Bulletin of the Riverview College Observatory (New South Wales) for July, August and September 1940, has also been received. The Observatory is equipped with three Wiechert and two Mainka seismographs, the interpretation of the seismograms from which are given. The shock of July 31, 1940, was felt at Cape Nelson, Papua. The earthquake of September 12, 1940, was felt at Rabaul, New Britain, also in the Kokopo district, and at Wide Bay, Pondo, Namatanai and Buka. To this earthquake there were several strong aftershocks. The shock of September 21, 1940, was felt at Queanbeyan, New South Wales, but did no damage. Some deep-focus shocks were recorded, and some slight shocks lacked interpretation, since the area is to some extent troubled with microseisms.

\section{Earthquakes near America}

The United States Coast and Geodetic Survey, in co-operation with Science Service and the Jesuit Seismological Association, has made a preliminary determination of the epicentres of the earthquakes of February 9 and February 11. The former had its initial time $9 \mathrm{~h} .44 \cdot \mathrm{lm}$. G.M.T., and on a basis of reports from 22 seismographic stations the epicentre appeared to be at latitude $40 \cdot 7^{\circ} \mathrm{N}$., longitude $125.4^{\circ} \mathrm{W}$. This is in the Pacific Ocean just off the coast of California, in a well-known seismic region. The latter had its origin time $14 \mathrm{~h}$. $35.4 \mathrm{~m}$. G.M.T, and on a basis of reports from 18 seismographic stations the epicentre was calculated to be latitude $14.5^{\circ} \mathrm{N}$., longitude $94^{\circ} 0^{\circ} \mathrm{W}$. This is in the Pacific Ocean almost due west of Guatemala in Central America, also in a well-established seismic zone.

\section{University of London: Certificate in Natural History}

THE University of London has now published amended regulations (applicable for the duration of the present emergency) for its certificate of proficiency in natural history. The new scheme takes advantage of the fact that large numbers of urban teachers are now located in the country or at the seaside, and so presented with an opportunity of natural history study in the field which, under normal peace-time conditions, would have been impossible. The requirements embrace a directed course of private reading at home, attendance at a practical laboratory course of two weeks duration in the summer, an approved plan of field-work suited to the student's locality to be written up in the form of a substantial essay, and examination. Copies of the regulations and syllabus can be obtained from the University Extension Registrar, University of London, at Royal Holloway College, Englefield Green, Surrey. Several local education authorities are prepared to consider sympathetically applications for financial grants-in-aid from teachers in their areas who wish to study for the certificate.

\section{Occurrence of Larger Fungi in the Tropics}

A BRIEF note by E. J. H. Corner (Trans. Brit. Mycol. Soc., 24, 3 and 4; Dec. 1940) again directs attention to the interesting question of the occurrence of the larger fungi in the tropics. His experience in Malaya is in emphatic contrast to that of $\mathbf{G}$. B. Masefield (ibid., 24, 64-67 ; 1940), who had suggested that large fleshy fungi are scarce in number and variety 